\title{
EFFECT OF SELECTED DEMOGRAPHIC VARIABLES ON TEACHER MOTIVATION IN SECONDARY SCHOOLS OF LAHORE, PAKISTAN
}

\author{
Shahida Nasreen \\ PhD Scholar, \\ Department of Education, University of Management \& Technology, \\ Punjab, Pakistan \\ Email: 2004sj@gmail.com

\section{Madiha Shah} \\ Assistant Professor, \\ Department of Education, University of Management \& Technology, \\ Punjab, Pakistan \\ Email: madihashah.phd@gmail.com
}

\begin{abstract}
Teacher motivation has been directly linked with teachers' job performance (Inayatullah, \& Jehangi, 2012; Nyakongo, 2015), classroom effectiveness (Carson \& Chase, 2009) and students' academic outcomes (Guajardo, 2011). The study was intended to assess the level of teacher motivation as perceived by private secondary school teachers working in Lahore, Pakistan. It also examined the effect of selected demographics (gender, age, academic qualification, and professional experience) on teacher motivation. A questionnaire namely Work Extrinsic and Intrinsic Motivation Scale (WEIMS) was administered to more than 700 teachers in 24 private schools located in Lahore. A total of 530 teachers' responses were gathered. Frequencies, percentages, mean, and standard deviations were calculated to assess the level of teacher motivation. Inferential Statistics ( $t$-test, One-way ANOVA) were applied to analyze the statistically significant differences (if any) among teachers grouped on the basis of gender, age, academic qualification, and professional experience. The results indicated that the respondent teachers had higher intrinsic motivation than the extrinsic motivation while no significant differences were observed when teachers were compared based on gender, age, and academic qualifications. However, significant differences were identified among teachers with different span of professional experience. Teachers with the least experience were found to be highly motivated as compared to highly experienced teachers.
\end{abstract}




\section{KEYWORDS}

Teacher motivation, Private schools, Academic qualification, Professional experience

\section{INTRODUCTION}

Teacher motivation has been directly linked with teachers' job performance (Inayatullah, \& Jehangi, 2012; Nyakongo, 2015). Many research studies have emphasized the significance of teacher motivation and proved that teachers who are satisfied with their profession produce good results and can arouse students' achievement in a better way (Bennell, \& Akyeampong, 2007; Guajardo, 2011). Teacher motivation has a significant effect on students' satisfaction with their learning and their success (Atkinson, 2000). Sargent and Hannum (2005) stated that teacher job satisfaction can be measured through his/her job involvement, work commitment, and teaching motivation and is positively correlated with teacher work performance.

\section{LITERATURE REVIEW}

The term motivation has been defined in several different ways by the researchers. Kim (2000) refers to motivation as an inner desire that urges and triggers interest in an activity. Green (2002) views motivation as an internal condition that starts, directs, and sustains behavior while Gagne (2004) regards it to be a state that assists the development of high achievement. Iliya and Ifeoma (2015) define motivation as an internal process that inspires a person to move towards a specific goal. Teacher motivation has been directly linked with classroom effectiveness and student learning achievements (Bennell \& Akyeampong, 2007; Carson \& Chase, 2009; Guajardo, 2011).

Sinclair (2008) defined teacher motivation in terms of "attraction, retention, and concentration as something that determines what attracts individuals to teaching, how long they remain in their initial teacher education courses and subsequently the teaching profession, and the extent to which they engage with their courses and the teaching profession".

The researchers distinguish two types of motivation; extrinsic and intrinsic motivation. Intrinsic motivation refers to the motivation that creates fun and enjoyment in a certain activity for its inherent satisfactions and not for other separable consequences such as external pressures and/or rewards (Ryan \& Deci, 2000). Extrinsic motivation is however, derived from the external and outside concerns of a certain activity. Self Determination Theory (SDT) explains extrinsic motivation as categorized into four different types namely; "integrated regulation, identified regulation, introjected regulation, and external regulation" (Ryan, \& Deci, 2000). Amotivation, on the other hand, is a state that reflects the absence of desire for a certain action. Eyal and Roth (2010) considered intrinsic motivation an outcome of autonomous motive and extrinsic 
motivation as a product of controlled motive.

Teachers with high level of motivation involve students in classroom learning and implement educational reforms (Nayakundi, 2012). Teacher motivation directly influences classroom effectiveness and leads to school improvement (Ofoegbu, 2004). Alam and Farid (2011) studied the factors that affect teacher motivation at secondary schools in Rawalpindi, Pakistan. Socio economic status of the teaching staff, the reasons behind their selection of the teaching profession, students' behavior, and job stress were the major factors that were highlighted by the researchers. In another study carried out by Adjei and Amofa (2014), pays and salaries were declared the most effective motivational factor for the employees.

Matoke, Okibo, and Nyamongo (2015) identified that developmental, environmental, leadership, and remuneration factors affect teacher motivation significantly. Developmental factors involved teachers' qualification, in-service training, and promotions whereas teaching and learning resources, working conditions and workload were part of environmental factors. Different leadership styles as chosen by the head of the institute added to leadership factors and remuneration factors included salary, rewards, and fringe benefits.

\section{RESEARCH OBJECTIVES}

1. To analyze the teachers' perceptions regarding their motivation in private secondary schools of Lahore

2. To examine the effect of demographic variables (gender, age, academic qualification, and professional experience) on teachers' perceptions regarding teacher motivation

\section{RESEARCH QUESTIONS}

1. What are the teachers' perceptions regarding their motivation in private secondary schools of Lahore?

2. Does teacher motivation differ between male and female teachers?

3. What is the effect of age on teacher motivation?

4. What is the effect of academic qualification on teacher motivation?

5. Does teacher motivation differ on basis of professional experience?

\section{RESEARCH METHODOLOGY}

A quantitative survey method was used to carry out this study. It was more appropriate for this type of study, as suggested by Ary, Jacob, Razavieh, and Sorensen (2006), to use a scale that could be filled by majority of participants in a shorter period and with nominal expenses. 


\section{Population and sample}

The population of the study included private secondary school teachers of Lahore. Through stratified random sampling, 24 schools from three different school types were selected and approached. These types included elite schools that target the affluent society, the middle class schools that focuses on teaching children from the middleincome group, and street schools that cater the educational needs of low-income families residing in Lahore. Data was collected from 530 teachers from 24 selected schools (7 elite, 11 middle-class, and 6 street schools).

\section{Instrumentation}

The present study followed a survey design aimed at examining the perceptions of the participants regarding their motivation level in schools. In this research, a structured questionnaire was used to gather data from the participants. It is easy and feasible for the participants to answer structured questionnaires (Ary et al., 2006). The total number of questionnaires administered was around 700, out of which 530 filled questionnaires were received making a response rate of $75.7 \%$. The questionnaire had two sections. Section A inquired four questions for recording participants' demographic information about their gender, age, academic qualification, and professional experience. In Section B, The "Work Extrinsic and Intrinsic Motivation Scale" (WEIMS) was used to measure teacher motivation. There are 18 items in this questionnaire, which are clustered in six subscales: "Intrinsic Motivation, Integrated Regulation, Identified Regulation, Introjected Regulation External Regulation, and Motivation".

The questionnaire was translated into Urdu language as English is the second language in Pakistan. It was done to ensure better understanding of all the items on the questionnaire. The reliability for the WEIMS scale was found to be 0.82 .

\section{DATA ANALYSIS AND RESULTS}

Data were analyzed by using both the descriptive as well as inferential statistics. Distribution of the participants according to the demographic variables was represented through frequencies and percentages. The participants' perceptions regarding their motivation were determined by using frequencies and percentages of their responses. Moreover, mean and standard deviation were also computed. Independent sample t-test was applied to analyze the statistically significant differences (if any) in teachers' perceptions about teacher motivation based on gender. One-way ANOVA was used to analyze the differences in teachers' perceptions regarding teacher motivation grouped on the basis of age, academic qualification, and professional experience. Furthermore, post hoc tests were performed to further explore where the differences occurred between groups. 
Table 1 shows that the majority of the sample teachers (419) were females, which constituted $79 \%$ of the total sample and around $21 \%$ of the teachers, were male. This difference in the ratio of male and female secondary school teachers was the true representation of the whole population as mostly female teachers are preferred to teach even in boys' secondary schools in private sector of Lahore. Most of the teachers (53.2\%) were 20-29 years old, whereas only $5.1 \%$ teachers were of the age of 50 and above. More than half of the teachers (59\%) were Master's Degree holder and only $10.2 \%$ were either M.Phil. or pursuing doctoral studies. A very small number of teachers $(5.5 \%)$ were Intermediate.

The largest percentage of secondary school teachers $(36.4 \%)$ reported that they have less than 5 years of experience in teaching. There were only $6 \%$ of the teachers who had 21 years or above of the teaching experience.

Table 1: $\quad$ Demographic Characteristics of the Respondents

\begin{tabular}{|c|c|c|c|}
\hline Variables & Category & $\begin{array}{c}\text { Frequency } \\
\text { (n) }\end{array}$ & $\begin{array}{c}\text { Percentage } \\
(\%)\end{array}$ \\
\hline \multirow[t]{2}{*}{ Gender } & Male & 111 & 20.9 \\
\hline & Female & 419 & 79.1 \\
\hline \multirow[t]{5}{*}{ Age } & $>20$ years & 27 & 5.1 \\
\hline & 21 to 30 years & 282 & 53.2 \\
\hline & 31 to 40 years & 132 & 24.9 \\
\hline & 41 to 50 years & 62 & 11.7 \\
\hline & $<50$ years & 27 & 5.1 \\
\hline \multirow[t]{4}{*}{$\begin{array}{l}\text { Academic } \\
\text { Qualification }\end{array}$} & Intermediate & 29 & 5.5 \\
\hline & Undergraduate & 135 & 25.4 \\
\hline & Graduate & 312 & 58.9 \\
\hline & Postgraduate & 54 & 10.2 \\
\hline \multirow{5}{*}{$\begin{array}{l}\text { Professional } \\
\text { Experience }\end{array}$} & $>5$ years & 287 & 54.2 \\
\hline & 6 to 10 years & 122 & 23.0 \\
\hline & 11 to 15 years & 64 & 12.1 \\
\hline & 16 to 20 years & 25 & 4.7 \\
\hline & $<21$ years & 32 & 6.0 \\
\hline
\end{tabular}




\section{Participants' Perceptions Regarding Teacher Motivation}

The information regarding what the respondents perceived of their motivation at their work place was gathered through WEIMS. Responses to the items in this scale ranged from 1 (strongly disagree) to 5 (strongly agree). Frequencies and percentages as well as the mean and standard deviation of the responses were computed which will be discussed with respect to the sub-scale they belonged to.

Most of the respondents (92\%) admitted that they derived pleasure from learning new things at work. Almost $84 \%$ of the respondents experienced satisfaction from taking on interesting challenges as well as from success at doing difficult tasks. Overall, the responses for all the items in the subscale namely 'Intrinsic Motivation' indicated that most of the respondents perceived themselves as intrinsically motivated. Majority of the teachers opined that their job had become an essential and basic part of their personality (83\%) and of their life too (85\%).

The findings for the subscale 'Identified Regulation' indicate that motivation played a major role in building up professional motivation among teachers. Most of the respondents agreed that they had chosen teaching to attain a certain lifestyle (73\%); to accomplish career goals (79\%); and to achieve certain important objectives in life $(76 \%)$.

The results of the items incorporated in subscale, 'Introjected Regulation' illustrated that the vast number of private school teachers internalized the external controls regarding their jobs. Almost $80 \%$ of the participants wanted to be successful in their jobs in order to avoid shame and a similar number of teachers $(80 \%)$ did not want to face disappointment in their work. Around $76 \%$ of the respondents wish to feel like a "winner" in their lives. The analysis of the responses related to 'External Regulation' indicated that $80 \%$ of the teachers considered that the profession of teaching provided them with security which was somehow more important to them as compared to income $(58 \%)$ or money (64\%) earned from their jobs.

Sixty three percent $(63 \%)$ of the respondents disagreed that they were unable to handle the tasks related to their work. To the question asking about the unrealistic working conditions, $18.7 \%$ strongly agreed that they were provided with such situations and nearly $54 \%$ of the respondents agreed that their jobs sometimes expected too much from them.

\section{Table 2: $\quad$ Teachers' Perceptions Regarding Teacher Motivation}

\begin{tabular}{rll}
\hline Sub-scales in TM & Mean & SD \\
\hline Intrinsic Motivation (IM) & 4.30 & .612 \\
\hline
\end{tabular}




\begin{tabular}{lll}
\hline Integrated Regulation (IR1) & 4.16 & .7387 \\
Identified Regulation (IR2) & 4.03 & .721 \\
Introjected Regulation (IR3) & 4.12 & 1.003 \\
External Regulation (ER) & 3.79 & .889 \\
Motivation (LM) & 3.09 & .915
\end{tabular}

Note. $\mathrm{N}=530$

The research findings, as mentioned by Table 2, indicate that the respondent teachers had higher level of Intrinsic Motivation (IM). Among the extrinsic motivation subscales, the teachers had the highest level of motivation in Integrated Regulation (IR1) followed by Introjected Regulation (IR3), Identified Regulation (IR2), and External Regulation (ER) respectively. Motivation (LM), which is considered as lack of motivation, was found to have the least mean values.

\section{Effects of Demographic Variables on Teacher Motivation}

The study intended to examine the effects of demographic variables including gender, age, academic qualification, and professional experience on teachers' perceptions regarding their professional motivation. In this section, the effects of all demographic variables are measured and analyzed.

Respondents' gender and teacher motivation. To determine the differences between male and female teachers regarding their perceptions for teacher motivation at the workplace, t-test was administered. Table 3 showed that male and female teachers had almost similar means on all the sub-scales of teacher motivation. No statistical significant differences were found between male and female private secondary school teachers regarding their perceptions on motivation.

Table 3: $\quad$ Results of t-test showing Differences between Male and Female Teachers' Perception

\begin{tabular}{cccccccc}
$\begin{array}{c}\text { 'Work Extrinsic and } \\
\text { Intrinsic Motivation } \\
\begin{array}{c}\text { Scale' (Sub-scales) } \\
\text { Scale }\end{array}\end{array}$ & Mean & SD & \multicolumn{2}{c}{$\begin{array}{c}\text { Female } \\
(\mathbf{n = 4 1 9})\end{array}$} & t & df & Sig. \\
\hline Mean & SD & & & \\
\hline IR & 4.27 & .585 & 4.30 & .619 & -.456 & 528 & .648 \\
IR2 & 4.19 & .738 & 4.15 & .739 & .548 & 528 & .584 \\
IR3 & 4.05 & .829 & 4.02 & .691 & .345 & 152.83 & .730 \\
ER & 4.17 & .504 & 4.10 & .820 & .447 & 127.81 & .655 \\
\hline
\end{tabular}




\section{Respondents' age and teacher motivation}

One Way ANOVA was applied to find out if there is any difference between teacher motivation based on teachers' age. Table 4 provides statistical evidence $(\mathrm{F}=1.552, \mathrm{df}$ $=4,524, p=.186>0.05)$ that teacher motivation was almost similar for all age groups. It can be assumed that motivation among teachers did not change with age.

Table 4: $\quad$ Result of One Way ANOVA showing No Differences in Perceptions among Age Groups

\begin{tabular}{lccclc}
\hline & Sum of Squares & df & Mean Square & F & Sig. \\
\hline Between Groups & 1.917 & 4 & .479 & 1.55 & .186 \\
Within Groups & 161.78 & 524 & .309 & & \\
Total & 163.69 & 528 & & & \\
\hline
\end{tabular}

\section{Respondents' academic qualification and teacher motivation}

To find out the differences in teacher motivation based on teachers' academic qualifications, One Way ANOVA was performed. Table 5 indicates that teacher motivation for all the groups was nearly similar $(\mathrm{F}=1.257, \mathrm{df}=3,525, p=.289>0.05)$ showing no statistical significant difference.

Table 5: $\quad$ Result of One Way ANOVA showing Differences in Perceptions among Academic Qualification Groups

\begin{tabular}{llcccc}
\hline & Sum of Squares & df & Mean Square & F & Sig. \\
\hline Between Groups & 1.167 & 3 & .389 & 1.257 & .289 \\
Within Groups & 162.530 & 525 & .310 & & \\
Total & 163.698 & 528 & & & \\
\hline
\end{tabular}

\section{Respondents' professional experience and teacher motivation}

Table 6 shows that teacher motivation changes with teacher professional experience. Statistical significant differences were observed among different groups based on experience $(\mathrm{F}=5.087$, df $=4,524, p=.000<0.05)$, therefore, Post Hoc Test was applied to further probe which groups of teachers were showing these differences.

Table 6: $\quad$ Result of One Way ANOVA showing Differences in Teacher Motivation among Different Professional Experience Groups

\begin{tabular}{llcccc}
\hline & $\begin{array}{l}\text { Sum of } \\
\text { Squares }\end{array}$ & df & $\begin{array}{c}\text { Mean } \\
\text { Square }\end{array}$ & F & Sig. \\
\hline Between Groups & 6.119 & 4 & 1.530 & 5.087 & .000 \\
Within Groups & 157.58 & 524 & .301 & & \\
Total & 163.69 & 528 & & & \\
\hline
\end{tabular}

The results of the Post Hoc Test (Table 7) show that teachers with different professional experiences were arranged in two groups according to their mean values 
for teacher motivation. It was interesting to note that teachers having 6-10 years' of teaching experience had the highest mean $(M=4.10)$ while the group of teachers having 16-20 years of teaching experience showed the least mean value $(M=3.77)$.

Table 7: $\quad$ Result of Post Hoc Test showing Differences in Teacher Motivation among Different Professional Experience Groups

\begin{tabular}{llcc}
\hline $\begin{array}{l}\text { Groups } \\
\text { (Professional Experience) }\end{array}$ & N & \multicolumn{1}{c}{ Subset for alpha $=\mathbf{0 . 0 5}$} \\
16 to 20 years & 25 & 3.77 & $\mathbf{2}$ \\
$>$ 21 years & 32 & 3.83 & \\
< 5 years & 287 & 3.85 & 3.83 \\
11 to 15 years & 64 & 3.94 & 3.85 \\
6 to 10 years & 121 & & 3.94 \\
Sig. & & .417 & 4.10 \\
\hline
\end{tabular}

\section{DISCUSSION AND CONCLUSION}

The research findings indicated that the respondent teachers had higher intrinsic motivation than the extrinsic motivation. In extrinsic motivation, the teachers had the highest level of motivation for 'Integrated Regulation' followed by 'Introjected Regulation', 'Identified Regulation', and 'External Regulation' respectively. The majority of teachers in private schools perceive that teaching as a profession offered them with many opportunities to learn new things, take on interesting challenges, and embark on difficult tasks. Teachers regard teaching as being personally important to them. They view their profession as a fundamental part of their lives and lifestyle. Teachers to satisfy some internal contingencies adopt the profession of teaching. They want to succeed at their work and become a winner. Teachers seem to give the teaching profession due value and importance as it helps them to attain their career goals and enjoy a certain lifestyle. Some teachers choose the profession of teaching for the sake of certain benefits like salary and job security. The respondent teachers also highlighted that their jobs are provided with unrealistic working conditions such as ensuring $98 \%$ of the attendance, $100 \%$ of student performance, and maintenance of extreme discipline during classroom teaching. Overall, the teachers did not show lack of motivation.

Many studies support the argument that gender is not related to teacher motivation (Wanakacha, Aloka, \& Nyaswa, 2018; Clifford, 2015; Recepoglu, 2013). However, there are some researches that found female teachers to be more motivated as compared to their male counterparts (Lee, Rhee, \& Rudolf, 2019) and some showed the reverse results (Triyanto, 2016). The current study finds no significant differences 
between male and female teachers regarding teacher motivation. Similarly, no significant differences in teacher motivation were observed among different age groups. The findings of the present study reinforce some previous researches (Tanriverdi, 2007; Wiyono, 2016) which illustrate similar results.

Academic qualification, analogous to gender and age, was found to have no effect on teacher motivation. Highly qualified and the least qualified teachers experience similar teacher motivation levels. These findings align with some previous researches (Tanriverdi, 2007; Wiyono, 2016) while contradicts with the results of Triyanto (2016) wherein the researcher concluded that teachers with higher qualifications are less motivated.

Groups of teachers with different professional experiences illustrate significant differences in their motivation level. The study showed that teachers having 6 to 10 years of teaching experience were on the highest level of teacher motivation followed by teachers with 11 to 15 years of teaching experience. On the other hand, the teachers with job tenure of 16 to 20 years had the lowest motivation. It means that junior teachers have higher motivation as compared to their senior colleagues. Teachers in Pakistan lose their motivation with the passage of time. This finding is supported by Triyanto (2016) who claims that as the professional experience of teacher's increases, their motivation level declines.

\section{RECOMMENDATIONS}

The study concluded that the teachers in private secondary schools of Lahore are intrinsically motivated. Gender, age, and academic qualifications do not affect teacher motivation, however, professional experience shows a negative impact on motivation level of public school teachers. School administration could utilize intrinsic motivation in the best possible way to enhance school success. They should work on strategies that are aimed at raising teacher motivation especially among senior employees. To elevate teachers' extrinsic motivation, good salary packages should be offered with other fringe benefits. School management should focus on enhancing collegial relationships among their staff members to elevate their motivation level.

\section{REFERENCES}

Adjei, H., \& Amofa, A. K. (2014). Teacher motivation in senior high schools in the Cape Coast Metropolis. European Journal of Education and Development Psychology, 2(1), 18-25.

Alam, M., \& Farid, S. (2011). Factors affecting teacher motivation. International Journal of Business and Social Science, 2(1), 298-304.

Ary, D., Jacobs, L. C., Razavieh, A., \& Sorensen, C. (2006). Introduction to research in 
education (7th ed.). Belmont, CA: Thomson Wadsworth.

Atkinson, E. S. (2000). An investigation into the relationship between teacher motivation and pupil motivation. Educational Psychology, 20(1), 45-57.

Bennell, P., \& Akyeampong K. (2007). Teacher Motivation in Sub-Saharan Africa and South Asia. Researching the Issues 71, Department for International Development: Education Papers.

Carson, R. L., \& Chase, M. A. (2009). An examination of physical education teacher motivation from a self-determination theoretical framework. Physical Education and Sport Pedagogy, 14(4), 335-353.

Clifford, O. E. (2015). Gender difference among social studies teachers' competences in the use of the inquiry method in South Nigeria. Journal of Education and Practice, $6(23), 48-51$.

Eyal, O., \& Roth, G. (2011). Principals' leadership and teachers' motivation: Selfdetermination theory analysis. Journal of Educational Administration, 49(3), 256275.

Gagné, F. (2004). Transforming gifts into talents: The DMGT as a developmental theory. High Ability Studies, 15, 119-147.

Green, E. C. (2002). The influence of individual and work environment characteristics on trainee motivation and training effectiveness measures (Doctoral dissertation, ProQuest Information \& Learning).

Guajardo, J. (2011). Teacher motivation: Theoretical framework, situation analysis of Save the Children country offices, and recommended strategies. Fairfield, CT: Save the Children.

Iliya, A., \& Ifeoma, L. G. (2015). Assessment of teacher motivation approaches in the less developed countries. Journal of Education and Practice, 6(22), 10-17.

Inayatullah, A., \& Jehangir, P. (2012). Teachers' job performance: The role of motivation, Abasyn Journal of Social Sciences, 5(2), 78-99.

Lee, J., Rhee, D., \& Rudolf, R. (2019). Teacher gender, student gender, and primary school achievement: Evidence from ten francophone African countries. The Journal of Development Studies, 55(4), 661-679.

Matoke, Y. K., Okibo, W. B., \& Nyamongo, D. N. (2015). Determinants of teacher motivation in public secondary schools in Masaba South subcounty, Kenya. International Journal of Economics, Commerce and Management, 3(6), 139-160.

Nyakundi, T. K. (2012). Factors affecting teacher motivation in public secondary schools in Thika West District, Kiambu County Kenyatta University Nairobi-Kenya. (Unpublished Master's Dissertation).

Nyakongo, O. H. (2015). Influence of motivation on teachers' job performance in public secondary schools in Rachuonyio South sub-county, Homa-Bay County: Kenya (Doctoral Dissertation, Kenyatta University).

Ofoegbu, F. I. (2004). Teacher motivation: A factor for classroom effectiveness and school improvement in Nigeria. College Student Journal, 38(1), 81-90.

Recepoğlu, E. (2013). Investigating motivation of primary and secondary school teachers in terms of demographic variables according to teacher opinions: A case of Turkey. Problems of Education in the 21st Century, 51, 104-112.

Ryan, R. M., \& Deci, E. L. (2000). Intrinsic and extrinsic motivations: Classic definitions and 
new directions. Contemporary Educational Psychology 25, 54-67.

Sargent, T., \& Hannum, E. (2005). Keeping teachers happy: Job satisfaction among primary school teachers in rural northwest China. Comparative Education Review, 49(2), 173- 204.

Sinclair, C. (2008). Initial and changing student teacher motivation and commitment to teaching. Asia-Pacific Journal of Teacher Education, 36(2), 79-104.

Tanriverdi, S. (2007). A case study of the relationship between participatory school culture and the motivation of foreign language teachers. Unpublished Master's Thesis, Yeditepe University, Istanbul.

Triyanto, R. A. D. H. (2016). Teacher Motivation Based on Gender, Tenure and Level of Education. Stanisław Juszczyk, 199.

Wanakacha, C. K., Aloka, P. J., \& Nyaswa, P. (2018). Gender differences in motivation and teacher performance in core functions in Kenyan Secondary Schools. Academic Journal of Interdisciplinary Studies, 7(1), 89-95.

Wiyono, B. B. (2016). Comparation of teachers' work motivation based on gender, age, education level, work duration, rank, and school level. Journal of Education and Social Sciences, 3, 61-66. 